\title{
De magistrados, inquisidores, promotores de justiça e samambaias: um estudo sobre os sujeitos no processo em um sistema acusatório
}

\author{
Paulo César Busato ${ }^{1}$
}

Resumo: O artigo trata de analisar a posição dos sujeitos do processo à luz do novo projeto de Código de Processo Penal, especialmente do Promotor de Justiça. Reconhece-se a adoção de um perfil prevalentemente acusatório no projeto, ainda que não seja uma orientação plena. A partir desta perspectiva, busca-se analisar a iniciativa de produção probatória às partes, mantendo o juiz a distância, bem como a entrega efetiva do comando da investigação ao Ministério Público, como elementos capazes de situar o que deve ser a postura processual do Promotor de Justiça. Conclui-se pelo reconhecimento de uma tendência evolutiva do sistema processual brasileiro em direção a um modelo acusatório, estabelecendo as bases ideais da postura do Promotor de Justiça em um sistema desta ordem.

Palavras-chave: Sujeitos do processo. Ministério Público. Gestão da prova. Poderes investigatórios.
Abstract: The article attempts to analyze the position of subjects of the process under the new draft Criminal Procedure Code, especially the prosecutor. We recognize the adoption of a predominantly adversarial profile in the project, although not a full orientation. From this perspective, we seek to analyze the initiative to produce evidence to the parts, keeping the distance of the judge, and also the effective delivery of the command of the investigation to prosecutors as evidence to situate what must be the procedural posture of the prosecutor. It is the recognition of an evolutionary trend of the Brazilian legal system towards an adversarial model, establishing the basis of the ideal position of prosecutor in a system of this nature.

Keywords: Subjects of the process. Prosecutors. Management of the evidence. Investigative powers.

1 Professor de Direito Penal da Universidade Federal do Paraná e da FAE - Centro Universitário Franciscano, doutor em Problemas atuais do Direito Penal pela Universidad Pablo de Olavide, em Sevilha, Espanha, e promotor de Justiça no Estado do Paraná. E-mail: pbusato2005@yahoo.com 


\section{Introdução}

Qualquer comentário sobre os sujeitos no processo deve ir muito além do que simplesmente a análise do capítulo que corresponde a este título no Código de Processo Penal ou no projeto de sua reforma. Muito mais se o enfoque a ser dado é na figura do promotor de Justiça, que representa o sujeito responsável pela formulação, apresentação e defesa do caso penal, alvitrando a aplicação de pena no caso concreto.

Ainda assim, o artigo 58 do projeto diz muito, na medida em que estabelece, a um só tempo, que o Ministério Público zele pela ordem jurídica e pela concreta aplicação da lei.

Aqui, cumpre analisar o que possa ser esta ordem jurídica e esta correta aplicação da lei. A ordem jurídica é, sem dúvida, a ordem democrática instaurada pela Constituição da República. Este há de ser o filtro interpretativo da atuação do Ministério Público como parte representante do interesse social no procedimento penal.

A correta aplicação da lei, por seu turno, refere-se ao processo de criminalização secundária, especificamente no que tange ao espírito do projeto do novo Código, de adoção de um sistema preponderantemente acusatório que há de ser a base hermenêutica dos dispositivos em concreto.

Assim, não se pretende aqui ficar adstrito a uma discussão sobre as suspeições e impedimentos que afetam as partes, mas sim buscar entender, na dinâmica das sucessivas reformas processuais penais brasileiras, quais as transformações estruturais que afetam a posição dos sujeitos no processo, especialmente enfocado o papel que compete ao Ministério Público dentro dessas transformações.

Conquanto uma análise desta natureza que quisesse ser profunda e adequada demandasse o largo esforço de ver, sob o prisma do perfil adotado pelo Ministério Público, todos os tópicos do novo projeto, o espaço do presente escrito não comporta um trabalho de tal envergadura. Portanto, a opção tomada será simplesmente a de apontar dois tópicos que representam simbolicamente a dinâmica de todo o Código. 


\section{1ำ Transformação - a posição das partes e a produção probatória}

A primeira relação obrigatória para esta compreensão é a verificação do modelo de manejo probatório que as reformas processuais pretendem implantar, que sempre dita o norte do sistema processual.

É sabido que inexiste na prática legislativa um modelo de sistema jurídico processual penal que possa afirmar-se inteiramente acusatório ou inteiramente inquisitivo. Assim, que se fala, mais corretamente, de um sistema predominantemente acusatório ou predominantemente inquisitivo. Nessa dinâmica, é possível dizer que o sistema do processo penal brasileiro progressivamente ganha cores acusatórias (RANGEL, 2009, p. 51), já que veio historicamente marcado por um perfil inquisitivo (FEITOZA, 2008, p. 36), ${ }^{2}$ em primeiro lugar, a partir da determinação constitucional que estabelece de modo expresso o monopólio do manejo da acusação na pessoa do agente do Ministério Público. ${ }^{3}$

Ademais, e ainda com foco na Constituição, é forçoso reconhecer que o próprio princípio da divisão entre os poderes ${ }^{4}$ estabelece que a função punitiva é tarefa administrativa própria do executivo, enquanto a função de julgar é do judiciário (p. 39).

A própria afirmação do “Estado democrático de direito” exige que o Estado-juiz se submeta às limitações e não goze de um poder absoluto de produção das provas que amparariam seu próprio juízo (p. 39).

Isso afeta diretamente o papel do sujeito no processo porque a separação de funções de julgador e de acusador é elemento essencial do modelo acusatório, enquanto a sua cumulação é a marca do modelo inquisitivo (p. 32). ${ }^{5}$

2 Denílson Feitoza refere que “um ‘observador externo’ ao nosso sistema diria que nosso sistema não é acusatório, pode ser marcadamente informado pelo princípio inquisitivo”.

3 Cf. art. 129, I, da Constituição da República.

4 Art. $2^{\circ}$, da Constituição da República.

5 “As características fundamentais do sistema acusatório residem: a) na separação das pessoas e dos poderes dos que atuam no processo (o acusador, requerendo e perseguindo criminalmente; o juiz ou tribunal, julgando; e o acusado, podendo resistir e exercer o direito de defender-se); b) na exigência de que a atuação do órgão jurisdicional para decidir e os limites de sua decisão dependem da "ação processual” (requerimento) de 
Quanto mais se aproxima um sistema de um modelo acusatório, mais os resultados da aplicação processual se aproximam da realização de um escopo de justiça, em contraposição à pretensão de afirmação de verdade que é própria de um modelo inquisitivo.

O modelo inquisitivo, como se sabe, tem por base a ideia de que é possível, através do método processual, reproduzir a verdade absoluta dos fatos. Esta descoberta da verdade real seria a única forma de repetir, na justiça dos homens, o perfil da justiça divina, pois ela permitiria afirmar o que realmente aconteceu; assim, para atingi-la, seria válido o emprego de qualquer meio. Conforme refere Feitoza, “com esse tipo de raciocínio, os juízes inquisidores chegaram facilmente ao principal meio de prova em que utilizavam - a tortura -, tanto que inquisição e tortura são empregadas, muitas vezes como sinônimas” (p. 38).

Antes de tudo, é necessário dizer que a expressão verdade real absolutamente pleonástica - expressa pouco ou nada em termos jurídicos, já que a pretensão de qualquer sistema normativo é a afirmação de sua validade e não de qualquer verdade intrínseca. Como bem refere Claus Volk, "o empreendimento verdadeiramente empírico de remeter tudo ao observável, fracassou há muito tempo” (VOLK, 2007, p. 45).

Ademais, do processo é que não se pode esperar qualquer verdade, já que ele representa apenas uma pálida reprodução dos fatos e não os fatos por si mesmos (p. 61). ${ }^{6}$ Estes são irrecuperáveis, por muito que seja perfeita a reprodução probatória. Isto porque, uma variável, pelo menos, é absolutamente irrepetível: o tempo. A impossibilidade de repetir o tempo no processo inviabiliza a correta análise contextual em que se desenvolveu o fato. Como o julgamento é a posteriori, ele jamais poderá ser absolutamente verdadeiro, porque o transcurso do tempo transforma o contexto. ${ }^{7}$

um acusador e do conteúdo de sua ação (princípio do ne procedat iudex ex officio, ou nemo iudex sine actore); c) na possibilidade de resistência do acusado”. Identificando características semelhantes, cf. também Rangel (2009, p. 50).

6 Claus Volk classifica o intento de produzir uma verdade equivalente à correspondência do juízo ao fato, como uma tentativa quase infantil e deplorável.

7 “A primeira missão do juiz consiste, pois, em reconstruir os fatos tais como aproximadamente se deram na realidade. Este labor de reconstrução só pode ser 
A afirmação definitiva da democracia, que é uma das metas da sociedade do terceiro milênio, passa naturalmente pela superação da pretensão de afirmação da verdade pelo direito e sua progressiva substituição pela pretensão de justiça. ${ }^{8}$ Por um lado, porque a busca incessante de uma verdade absoluta implica em afirmações universais que vilipendiam o respeito pelas diferenças, base fundamental de qualquer democracia. E por outro, porque já se verificou que a pretensão científica de afirmação de uma verdade é algo completamente fora do alcance do direito ${ }^{9}$ que, por si, não é uma ciência, mas uma simples forma de argumentar, criação humana, produto de elucubração e portanto, essencialmente falível. Daí a necessidade de redução da pretensão de afirmação do direito. O direito pode buscar a realização de justiça. Não uma justiça absoluta, universal e irretocável, que é utópica, mas sim a justiça possível. Deve permanecer na busca do alcance da perfeição do justo, mesmo sabendo, de antemão, da sua material impossibilidade. Por outro lado, deve renunciar à pretensão de afirmar uma verdade histórica, porque esta, do ponto de vista do processo, foi o que deu azo à possibilidade de justificar o uso de quaisquer meios probatórios (FEITOZA, 2008, p. 33) - inclusive tortura - para sua produção.

A opção de afirmação democrática do processo somente se dá através da inclusão argumentativa, pela igualdade de oportunidade de discurso. ${ }^{10}$ Este modo de afirmação democrática se dá, em termos

aproximado, já que é impossível reproduzir o fato acontecido em todos os seus detalhes. A situação das pessoas e coisas muda com o tempo e tem que ser necessariamente distinto, em maior ou menor grau, o que sucedeu" (MUNÕZ CONDE, 2003, p. 3). Também se refere precisamente a isto quando, ao discutir o fundamento material da culpabilidade, afirma que a demonstração de que o sujeito poderia atuar de outro modo, diferentemente da forma como atuou é impossível (MUÑOZ CONDE; GARCÍA ARÁN, 2007, p. 351).

8 Nesse sentido, Vives Antón refere que a dogmática penal se equivocou em suas pretensões, ao substituir pela pretensão de verdade uma pretensão de justiça que deveria acompanhar suas estruturas conceituais (VIVES ANTÓN, 1996, p. 481).

9 "Efetivamente, as disposições não são detectáveis de maneira direta mediante a percepção: para investigá-las, é imprescindível observar formas de comportamento em determinadas situações. De modo algum se trata só de propriedades como interessam nas ciências naturais" (VOLK, 2007, p. 45).

10 Veja-se a fundamentação dos direitos pelo caminho da teoria do discurso, especialmente a afirmação do princípio da democracia, em Habermas (2003, p. 154). 
processuais, pela substituição de uma verdade material por uma verdade formal "legitimidade como produto de um processo discursivo e premiada idealmente mediante o consenso dos participantes”, ${ }^{11}$ o que só pode ser almejado em um processo de cariz acusatório. ${ }^{12}$

Uma das características básicas de um modelo predominantemente acusatório, do ponto de vista e dos sujeitos processuais, é a preservação da figura do juiz como destinatário da produção probatória processual, em uma posição distanciada e de equilíbrio, que permite ditar justiça. Como efeito, um sistema assim coloca as partes como antagonistas e senhoras da produção probatória, com iniciativa e impulsão do procedimento para o fim da demonstração de suas teses. ${ }^{13}$

Esta postura fica evidente no projeto de reforma do Código de Processo Penal, já em sua exposição de motivos, quando, no item II, refere: "seja do ponto de vista da preservação do distanciamento do julgador, seja da perspectiva da consolidação institucional do Parquet, não há razão alguma para permitir qualquer atuação substitutiva do órgão da acusação pelo juiz do processo”. ${ }^{14}$

Esta referência deixa claro que o projeto pretende evitar a confusão entre a posição de acusador e de julgador, confusão esta que é justamente a marca concreta de um modelo inquisitivo.

Claro que o projeto preserva ainda, e assim refere, alguma participação do juiz na construção do processo, com isto demonstrando ainda não ter assumido completamente o perfil acusatório, já que afirma que "não se optou pelo juiz inerte", ${ }^{15}$ introduzindo a figura de um juiz de

11 VOLK, Claus. La verdad sobre la verdad y otros estudios...op. cit., p. 71.

12 “[...] o modelo da verdade formal interessa no aspecto que exige uma intensificação da comunicação e reclama o poder jurídico para participar no processo de busca da verdade. Na prática, os elementos inquisitivos de nosso procedimento são induvidosos. Eliminálos e substituí-los mediante a sã competição entre as diferentes apresentações do caso formuladas pelas partes é certamente discutível [enquanto possibilidade concreta], mas não o é o objetivo daquela idéia diretriz”. Idem, p. 72.

13 FEITOZA, Denilson. Reforma Processual Penal...Op. cit., p. 36.

14 Item II da Exposição de motivos do projeto de Código de Processo Penal.

15 Item II da Exposição de motivos do projeto de Código de Processo Penal. 
garantias, responsável inclusive pela adoção de medidas cautelares “quando destinadas a protelar o regular exercício da função jurisdicional”. ${ }^{16}$

Ora, mesmo que se reconheça como ideal que o sujeito juiz permaneça afastado de modo absoluto da interferência no processo, não ser o juiz inerte, neste caso, destina-se tão somente a colocar o juiz na condição de garantidor do regular exercício da prestação jurisdicional e não da produção de qualquer classe de resultado. Menos ainda de um resultado "pretendidamente” verdadeiro, o mito que há muito foi soterrado no âmbito das pretensões de realização do processo. ${ }^{17}$

Convém notar que, neste sentido, o projeto apenas confirma uma tendência já antes anunciada pela atitude do legislador brasileiro, que, já com o advento da Lei n. 11.690/2008, que alterou o artigo 212 do Código de Processo Penal, e da Lei n. 11.689/2008 que alterou o artigo 473, caput do mesmo diploma, já adotou, antes mesmo do advento do projeto de reforma, um sistema semelhante ao cross examination do processo penal estadunidense, uma vez que as perguntas são formuladas pelas partes diretamente às testemunhas, colocando o juiz à distância da prova, cuidando apenas de não admitir as perguntas que poderiam induzir resposta, ou não tiverem relação com a causa, ou importarem em repetição desnecessária, cumprindo-lhe tão somente complementar os pontos não esclarecidos pelas partes, na forma do parágrafo único do mesmo artigo 212.

A mesma fórmula é repetida no projeto de reforma em seu artigo 175, com a inserção ainda de um parágrafo $2^{\circ}$ no qual se esclarece que, se das respostas dadas aos esclarecimentos complementares formulados pelo juiz, surgirem novos fatos ou circunstâncias, o juiz abrirá nova possibilidade às partes de formularem perguntas. E isso deixa claro a quem pertence a formulação probatória, ou seja, justamente àqueles que

${ }^{16}$ Item II da Exposição de motivos do projeto de Código de Processo Penal.

17 "O objeto do processo penal é a obtenção da verdade somente na medida em que se empreguem para isso os meios legalmente reconhecidos. Se fala assim de uma "verdade forense" que nem sempre coincide com a verdade material propriamente dita. Este é o preço que se deve pagar por um processo respeitoso com as garantias e direitos humanos característicos do Estado social e democrático de Direito" (MUÑOZ CONDE, 2003, p. 112). 
se dirigem diretamente à testemunha. O juiz é colocado em uma condição de distância relativa da prova testemunhal como forma de garantir sua isenção para julgar.

Nesse sentido caminha a melhor doutrina. Refere Antônio Alberto Machado a adoção clara do formato estadunidense do cross examination:

Por força do disposto no art. 212 do CPP, as perguntas serão formuladas pelas partes diretamente às testemunhas, ou seja, a tomada dos depoimentos testemunhais não é feita pela forma presidencialista, segundo a qual o juiz procede à inquirição do depoente e, em seguida, formula também as perguntas requeridas pelas partes, centralizando em si todo o ato do depoimento. O juiz deverá inquirir a testemunha após as partes, de forma complementar, apenas sobre pontos que eventualmente não ficaram esclarecidos durante a inquirição direta feita pela acusação e pela defesa (art. 212, parágrafo único, do CPP). Trata-se aqui da adoção do sistema de origem anglo-americano, denominado cross-examination, que favorece a efetividade do contraditório na medida em que o juiz permanece em posição equidistante da atividade probatória, observando a produção da prova pelas partes, de modo a preservar melhor a sua imparcialidade e isenção de ânimo.

$\mathrm{Na}$ verdade, esse sistema de colheita de depoimentos testemunhais, diretamente pelas partes, está bem de acordo com o princípio do processo acusatório, segundo o qual o juiz não deve protagonizar a produção das provas. Nesse tipo de processo, a prova deve ser sempre produzida pelas partes, às quais incumbe o ônus de demonstrar a veracidade de suas teses e alegações. O juiz, imparcial e isento, é apenas o destinatário da prova e não o seu autor. Portanto, a postura que mais lhe convém é mesmo a de observador do 'duelo probatório’, travado entre a acusação e a defesa, na busca dialética da verdade processual.

Na inquirição das testemunhas, o magistrado exercerá uma função essencialmente fiscalizatória, podendo indeferir as perguntas que venham a induzir respostas, as perguntas impertinentes que não tenham relação com a causa, e aquelas que importarem na repetição de outras perguntas já respondidas pelo depoente (art. 212, caput, do CPP). (MACHADO, 2009, p. 396). 
No mesmo sentido, a opinião do Denílson Feitoza:

[...] no CPP, com a nova redação dada pela Lei 11.690/2008 ao art. 212 e pela Lei 11.689/2008 ao art. 473, caput, do CPP, o sistema passou a ser semelhante ao cross examination ("exame cruzado") do processo penal estadunidense, uma vez que as perguntas serão formuladas pelas partes diretamente à testemunha.

O juiz passa a acompanhar as inquirições feitas diretamente pelas partes, não admitindo aquelas perguntas que puderem induzir a resposta, não tiverem relação com a causa ou impostarem na repetição de outra já respondida.

Doravante, o juiz após as inquirições das partes, poderá fazer suas perguntas para complementar aquelas sobre os pontos não esclarecidos (art. 212, parágrafo único, CPP). (FEITOZA, 2008, p. 256).

Comenta Eugênio Pacelli, um dos membros da comissão de elaboração do projeto do novo Código Penal, que a fórmula de produção de provas direta pelas partes é consequência da assunção de um perfil predominantemente acusatório:

A Lei no 11.690/08 trouxe importante alteração no procedimento de inquirição de testemunhas.

Ali se prevê que as perguntas das partes serão feitas diretamente à testemunha, não admitindo o juiz aquelas que puderem induzir a resposta, não tiverem relação com a causa ou importarem a repetição de outra já respondida (art. 212, CPP). E, mais ainda, prevê que o juiz poderá complementar a inquirição, sobre pontos eventualmente não esclarecidos (art. 212, parágrafo único, CPP).

Observa-se então, que a medida encontra-se alinhada a um modelo acusatório de processo penal, no qual o juiz deve assumir posição de maior neutralidade na produção da prova, evitando-se o risco, aqui já apontado, de tornar-se o magistrado um substituto do órgão de acusação. Assim, as partes iniciam a inquirição, e o juiz a encerra. (OLIVEIRA, 2009, p. 370).

Para Paulo Rangel, esta é precisamente a característica de um processo penal democrático: 
Em um processo penal democrático, banhado pelo sistema acusatório, o juiz deve ser afastado da colheita de provas, deixando tal tarefa às partes. Se o sistema é o todo e não uma parte, não pode o processo ter momentos em que seus atos serão a luz da estrutura acusatória e outros a luz de uma estrutura inquisitória. Isso não é sistema. Logo, em audiência não poderia ser diferente.

Sistema acusatório ( $c f$. item 2, supra) não é apenas o MP promover, privativamente, a ação penal pública, mas sim a necessidade que se busca no processo (por isso sistema) de se afastar o juiz da persecução penal, mantendo sua imparcialidade e retirando de suas mãos a gestão da prova. [...]

A colheita de depoimentos pelo juiz passou a ter uma função supletiva, ou seja, se ele entender que há algum ponto não esclarecido, poderá complementar a inquirição, mas note-se bem: é sobre pontos não esclarecidos, ou seja, algo relevante ao julgamento do caso penal que envolve aquele depoimento. Trata-se de ponto substancial e não acidental do depoimento.

Óbvio, nos parece, que as partes, em primeiro lugar, iniciam as perguntas para, só depois, o juiz fazer as perguntas que entender cabíveis, em função supletiva. Para evitar contaminação do juiz devem as partes ditarem, diretamente, ao secretário que estiver digitando os depoimentos, o que está sendo dito pelas testemunhas, sem passar pelo juiz.

Esta tendência do processo penal brasileiro a respeito da prova diz muito sobre a situação dos sujeitos no processo. Revela claramente que a condição do Ministério Público é, definitivamente, a de parte, enquanto a do juiz é a de destinatário da produção da prova pelas partes e de responsável pela oferta de respostas às demandas de justiça submetidas ao Estado.

As reformas, tanto a intermediária, oriunda de leis pontuais, quanto a do próprio projeto completo, orientam-se na mesma linha, qual seja, a de acabar definitivamente com uma postura inerte e irresponsável de alguns agentes do Ministério Público que simplesmente a partir do oferecimento da denúncia não mais se encarregavam de levar adiante seu caso, entregando-o lenientemente nas mãos do juiz e, por outro lado, de magistrados que, com perfil dominador, adiantavam-se na realização 
concreta processual do silogismo regressivo, escravizando a produção probatória em face de convicções adquiridas adrede a respeito do resultado e que convertiam a missão de julgador, nas mais das vezes, em missão de vingador.

A própria criação de um juiz de garantias evidencia a necessidade aventada no item III da exposição de motivos, de "manter o distanciamento do juiz do processo, responsável pela decisão de mérito em relação aos elementos de convicção produzidos e dirigidos ao órgão da acusação”. ${ }^{18}$

Aqui é necessário fazer uma advertência a respeito das dificuldades de implantação de uma nova cultura. Trata-se da absoluta necessidade de superação de um modelo enraizado em nossa tradição de diferenças que dependerá, e muito, de uma consciência dos sujeitos do processo no sentido de darem efetividade ao modelo. Conforme aduz Feitoza, “O juiz brasileiro deve ter a coragem, a força moral e o senso crítico necessário para assumir sua missão, implementando a Constituição com observância do princípio da supremacia constitucional, que lhe impõe e possibilita o reconhecimento da inconstitucionalidade das normas infraconstitucionais que sejam incompatíveis com o princípio acusatório constitucional” (FEITOZA, 2008, p. 39).

Vale dizer: é fundamental que o Poder Judiciário reconheça a legitimidade do princípio acusatório e a sua condição de julgador distanciado da prova, como modo de efetivar a sua afirmação como Poder da República, distanciado e independente das diretrizes de controle social acusatório do executivo.

Entretanto, o que se tem observado é uma impressionante resistência verdadeiramente ativa à implantação das diretrizes de um sistema acusatório. Não se trata apenas da notória rejeição do novo, ${ }^{19}$ mas sim de uma disputa sobre o poder, ainda que dele, o resultado do processo penal seja apenas uma parcela ínfima.

18 Item III da Exposição de motivos do projeto de Código de Processo Penal.

19 “Será difícil os magistrados brasileiros se curvarem à nova maneira de agir e pensar o processo penal; afinal, são mais de sessenta anos fazendo dessa forma. Contudo, o desafio será exatamente esse: olhar novo (Lei $\left.{ }^{\circ} 11.719 / 08\right)$ com os olhos do novo e não com os olhos do velho (CPP, de 1941)” (RANGEL, p. 505). 
É sabido ser impossível uma mudança cultural a golpes legislativos. Não há ilusões a respeito de que a mudança legislativa seja por si só a responsável por qualquer câmbio sociológico. De outro lado, é necessário reconhecer que a evolução da cultura jurídico-processual-penal brasileira, claramente representada por muitos dos presentes neste evento, foi responsável por uma mudança de mentalidade não só do ambiente acadêmico, mas da praxis forense relativa ao processo penal que alcançou, finalmente, a instância legislativa. Esta mudança de pensamento, que é irreversível vê-lo, encontra, porém, a fervorosa resistência daqueles que, apegados à ínfima parcela do poder, são renitentes em abrir mão de uma evolução que representa maior dignidade à sua posição no processo.

Refiro-me, aqui, à nota publicada recentemente na página web da Associação dos Magistrados do Estado do Paraná, apontando um determinado acórdão do Tribunal de Justiça Paranaense como paradigma da interpretação a ser dada ao artigo 212 do atual código de processo penal pela com redação ditada pela Lei n. 11.690/2008, que equivale ao artigo 175 do projeto de reforma do Código de Processo Penal. O acórdão foi de tal forma publicizado com evidente pretensão de orientar a atuação dos magistrados paranaenses.

Trata-se do acórdão lavrado no agravo regimental crime n $413.084-$ 9/01, votado pelo Órgão Especial do Tribunal de Justiça do Paraná, que teve por relator o Desembargador Leonardo Lustosa, no qual se sustenta que a interpretação a ser dada ao artigo retroindicado, é de que o juiz deve prevalecer no comando da inquisição das testemunhas, fazendo ele, primeiramente, as perguntas que tenha sobre o fato, apenas permitindo que, de modo complementar, as partes possam inquirir diretamente as testemunhas.

A lamentável ementa tem o seguinte teor:

Agravo regimental. Ação penal originária intentada contra Procurador de Justiça. Exceção da verdade. Inquirição de testemunha arrolada pelo excipiente. Alegação de inobservância do disposto no art. 212 do Código de Processo Penal (redação dada pela Lei ${ }^{\circ}$ 11.690/08). Ofensa ao sistema acusatório. Inocorrência. Ausência de prejuízo concreto. Nulidade inexistente. Recurso desprovido. 
1) A nova redação do art. 212, caput, do Código de Processo Penal, dada pela Lei $\mathrm{n}^{\circ} 11.690 / 08$, nada altera quanto à iniciativa das perguntas, possibilitando, tão somente, que as partes formulem diretamente, sem necessidade de as dirigirem ao magistrado.

2) Por seu turno, o parágrafo único do art. 212 do CPP, introduzido pela mencionada lei, também não significa que o juiz pergunta por último, mas apenas que, embora as demais perguntas sejam formuladas diretamente pelas partes, pode o juiz obter esclarecimentos a qualquer tempo.

3) Com absoluta propriedade, o saudoso Ministro Francisco Campos, na Exposição de Motivos do Código de Processo Penal, já alertava que "o projeto não deixa respiradouro para o frívolo curialismo, que se compraz em espiolhar nulidades. É consagrado o princípio geral de que nenhuma nulidade ocorre se não há prejuízo para a acusação ou a defesa.

Nem sequer é o evidente equívoco hermenêutico da Corte o que mais chama a atenção, inclusive porque este certamente pode ser objeto de fácil diluição pela via recursal. O espantoso, e ao mesmo tempo lamentável, é o evidente esforço no sentido de distorcer os termos da legislação e dos próprios princípios que a orientam para satisfazer uma pretensão de poder, e ao mesmo tempo de afirmação da unção do magistrado como único ser capaz de realização do justo, diante da iniquidade das partes.

Esta fantasia megalômana fica bem evidente de certas passagens do voto condutor do julgado, senão vejamos.

Em primeiro lugar, o voto se socorre do que qualifica de lição precisa lançada por Guilherme de Souza Nucci - não por acaso, magistrado - em apoio de sua tese, pois, “caso contrário, só restaria ao juiz assistir à audiência, indeferindo uma pergunta aqui e outra acolá, podendo, ao final, apenas complementar a inquirição, concluindo, então, que os defensores dessa tese querem transformar os juízes em samambaia de sala de audiências".

Nota-se aqui, a imensa preocupação do voto para com o juiz inerte em relação à produção probatória, que não é enxergado em sua nobreza e equidistância capaz de permitir uma apreciação isenta de pré-julgamentos, mas sim na diminuta condição de vegetal decorativo. 
Ocorre que, ao contrário do pensamento revelado pelo voto, o distanciamento do juiz em face da produção probatória, em nada o diminui (RANGEL, 2009, p. 505-506). Na verdade, é justamente este afastamento, esta isenção, que permite o real controle sobre a realização das provas pertencente às partes, pois somente uma prudente distância dos interesses debatidos na causa permite que o juiz exerça sua função de garantir os direitos fundamentais do acusado. A ele incumbirá justamente evitar a realização de pressão sobre a testemunha, controlando o deferimento ou indeferimento de perguntas.

Evidentemente, o ilustre relator revela sua preferência por ocupar a condição de inquisidor. O voto trai sua pretensão quando afirma textualmente que pretende a busca da verdade a qualquer preço, ao afirmar: "uma das características mais marcantes do processo penal é a vigência do princípio da verdade real, não devendo o juiz se satisfazer com a verdade formal (aparente) que lhe é exibida pelas partes, mas buscar, por todos os meios admissíveis no processo, alcançar a verdade histórica, independentemente ou para além da contribuição da acusação e da defesa”.

Resta clara aqui a postura anacrônica, falsa e pretensiosa de afirmação de uma verdade que se sabe, de antemão, inalcançável. Lamentavelmente, "essa cultura milenar e ideológica de alcance de uma verdade real e de realização de uma justiça divina continua a impregnar nosso cotidiano forense” (FEITOZA, 2008, p. 38).

E em outra passagem, afirma sua condição de ungido, comparando a capacidade do juiz à das partes para a geração da verdade real, deixando claro que só o primeiro é capaz de alcançar a paz social. Diz o voto: “a inquirição efetivada nos moldes ora criticados não constitui, de forma alguma, atentado ao sistema acusatório, mas atribui, sim, ao julgador [...] o indelegável mister de, após a descoberta da verdade real - a qual, por óbvio, jamais poderia ser atribuída à acusação nem à Defesa e muito menos poderia ser obtida com sua inércia no curso do processo - aplicar o direito ao caso concreto visando à pacificação social com Justiça”.

Ao contrário do que afirma o voto, é justamente a negação da adoção do cross examination que revela afastamento do sistema acusatório, 
caracterizado pelo distanciamento entre o juiz e a produção da prova, ${ }^{20}$ deixando clara sua opção pela preservação de um modelo inquisitorial que foi o instrumento de afirmação do modelo feudal e da Igreja católica, na Idade Média, através da persecução pública e indiscriminada de seus inimigos. ${ }^{21}$ Este modelo caracterizou-se precisamente pela crença na honestidade fundamental do inquisidor e em sua capacidade, mediante métodos ilimitados (inclusive a tortura) de chegar à verdade.

O magistrado se torna, no pensamento do culto e digno Desembargador, uma figura mítica, completamente isolada das metarregras condicionantes das decisões, um verdadeiro super-homem, um ser absoluto, muito acima da abjeta humanidade falível das partes, quando afirma: "Está o juiz no exercício de sua absoluta imparcialidade, eis que procura a isenta narrativa dos fatos, diferentemente do Ministério Público, a quem a Constituição federal atribui o dever de acusar (podendo, obviamente, requerer a absolvição ao final, se o caso) e da Defesa, que procurará, sempre, a melhor situação jurídica para o denunciado”.

20 “O sistema inglês é o que, na atualidade, mais se assemelha ao sistema acusatório antigo. O processo penal inglês é propriamente um processo de partes, pois em regra, o juiz não produz provas de ofício, coloca-se imparcialmente de maneira eqüidistante das partes e sua decisão se fundamenta no que foi alegado e provado pelas partes, não aplicando o fato apresentado na acusação, nem as provas produzidas” (FEITOZA, 2008, p. 32).

21 “O sistema processual penal inquisitivo ou inquisição se estendeu por toda a Europa continental do século XIII ao século XVIII [...] Desenvolveu-se em razão da convergência de interesses entre a igreja católica, que afirmava sua universidade e lutava contra os infiéis, e os estados nacionais sob regime de monarquia absoluta, que procuravam se firmar contra o poder feudal. Suas características fundamentais são: a reunião dos poderes de acusar e julgar nas mãos do órgão jurisdicional; a persecução penal pública, iniciada pelo próprio órgão jurisdicional, para não depender da vontade de um particular, a redução do acusado a mero objeto das investigações, deixando de ser sujeito de direitos; o estabelecimento da averiguação da verdade como objetivo principal do procedimento penal, para cuja obtenção admitam-se quaisquer meios, inclusive a tortura. [...] quanto à separação das figuras do acusador, do juiz e do defensor: como vimos, o acusador e o julgador estão na mesma pessoa ou órgão. Não havia defensor, pois, se o réu era culpado, não o merecia, se era inocente, um juiz inquisidor honesto o descobriria” (FEITOZA, 2008, p. 33). 
Este ser mítico, semidivino, não pode, na visão da Corte, abdicar de sua verdadeira cruzada. Ele foi escolhido para representar a paz social do mundo, e seu poder se converte em um verdadeiro fardo, que, com denodo, incumbe-lhe carregar. Na visão do voto, jamais poderá o juiz deixar a atividade de produção da prova às partes, pois estas cometem a heresia de defender os interesses de suas próprias teses. Sustenta o voto: “A prevalecer entendimento em sentido contrário, estaria o juiz, quiçá por comodismo, abdicando de seu poder-dever de, com imparcialidade, inquirir as testemunhas - imparcialidade esta que se faz necessária para analisar melhor os fatos e, assim, proferir justa decisão. [...] A preocupação existe porque não é incomum que a acusação - mormente no caso de haver Assistentes - queira, de forma apaixonada, provar a procedência da denúncia, e a Defesa, por sua vez, sustentar tese favorável ao acusado. Por isso, se iniciada a inquirição pelas partes, é evidente que muitas vezes haverá, ainda que sutilmente, condução das perguntas para obtenção das respostas esperadas - o que por certo não se verificará se a testemunha for inquirida, inicialmente, por magistrado ético”.

É tal a convicção do voto a respeito de estar correta a apropriação pelo Judiciário da produção probatória, bem como da presunção absoluta de sua imparcialidade e isenção na produção deste mister, que ele sequer consegue enxergar o evidente prejuízo de suspeição derivado da providência, pois o último argumento expendido é nada menos do que o seguinte: "em quarto lugar, ainda que se admitisse, apenas para argumentar, a existência do vício apontado pelo agravante, a verdade é que o seu eventual reconhecimento não prescinde da demonstração de efetivo e concreto prejuízo, consoante preconiza o art. 563 do Código de Processo Penal”, donde se conclui que o voto não viu qualquer prejuízo para as partes em sua postura.

Ora, o prejuízo existe, claríssimamente, no simples fato de que o juiz contaminou-se com a produção da prova. Há um evidente processo de silogismo regressivo. ${ }^{22}$

22 Consoante bem observa Juarez Cirino dos Santos, "Não é difícil perceber que a lógica de subsunção jurídica do silogismo pode apresentar problemas relacionados com a subjetividade do julgador, produzidos por duas espécies de erros, incidentes sobre objetos diferentes: a) o erro de interpretação das normas jurídicas; b) o erro 
É necessário afirmar que não se pretende fazer uma crítica institucional dirigida somente ao Judiciário, porque certamente a posição referida recebe o aplauso de alguns agentes do Ministério Público, que preferentemente optam por deixar ao juiz, por comodidade ou subserviência, o dever de produzir a acusação, desvirtuando com isso os mecanismos estabelecidos pelo sistema.

O resultado final desta postura é um evidente prejuízo às partes, especialmente à defesa quando o juiz assume a postura de acusador. Pouco resta a fazer em termos defensivos quando o destinatário de uma proposta acusatório é precisamente aquele que a formula.

A imagem simbólica da Samambaia utilizada pelo ilustre Desembargador mostra menos o risco a que fica exposta a figura do juiz num modelo acusatório do que o resultado que produz um modelo inquisitivo para a figura do promotor de Justiça. A postura referida no mencionado acórdão revela inconscientemente o modo como alguns membros do judiciário, ainda imbuídos do espírito de Torquemada, pretendem converter a figura do promotor de Justiça. Há uma clara diferença - que quiçá ainda escape àqueles que têm saudades de um Estado ditatorial - entre magistrados, inquisidores e samambaias. O que se deseja em um Estado social e democrático de direito é somente a primeira das três figuras.

A condição de sujeito do processo que corresponde ao Ministério Público é a de parte responsável pela formulação do caso a partir do qual pretende o provimento jurisdicional e ao mesmo tempo se responsabiliza

de análise da prova processual. O erro de interpretação da norma jurídica pode ser explicado por falhas ou defeitos no conhecimento científico do Direito; mas o erro de análise da prova - também definido como silogismo regressivo - é conhecido em criminologia como metarregras (ou basic rules, segundo a fenomenologia), produzido por mecanismos psíquicos inconscientes que determinam o significado concreto da decisão judicial: preconceitos, estereótipos, traumas e outras idiossincrasias originárias da experiência pessoal do julgador, desvendados por indicadores sociais negativos de pobreza, desemprego, marginalização, moradia em favelas, etc., constituiriam as determinações emocionais decisivas do processo de criminalização" (SANTOS, 2008, p. 68). Em resumo, "o juiz pode decidir por uma questão de gosto ou de preferência íntima” (BACILA, 2005, p. 172). 
que esta apresentação de caso se dê dentro dos parâmetros definidos pelo Estado Democrático de Direito. ${ }^{23}$

Este perfil adotado pelo Código de Processo Penal em sua a nova configuração certamente diz muito a respeito da posição do Ministério Público no processo.

O Promotor de Justiça, certamente, diante das reformas do processo, se verá compelido a assumir o seu papel de parte, tendo o controle e o conhecimento do processo para poder produzir a necessária prova para sustentar sua tese (RANGEL, 2009, p. 505-506). Não poderá mais adotar a postura passiva de mero espectador da iniciativa probatória do juiz. Este, por seu turno, terá que assumir uma postura real de imparcialidade na audiência, que começa por não participar da produção probatória, senão em caráter meramente suplementar.

É o promotor de Justiça o responsável pela apresentação de um caso que, inicialmente bem investigado, judicialmente é apresentado ao Estado-juiz para que pronuncie o resultado justo, atribuindo ou não uma pena. Esta análise leva obrigatoriamente ao segundo aspecto do projeto que conduz à identificação do sujeito processual promotor de Justiça. Refiro-me à posição do Ministério Público diante da investigação.

\section{2a Transformação: a posição do Ministério Público diante da investigação}

Um segundo aspecto, igualmente revelador da posição do Ministério Público enquanto sujeito do processo penal no projeto do novo Código aparece com a opção que é feita a respeito de sua posição no que tange à

\footnotetext{
${ }^{23}$ Observe-se que a própria Constituição da República estabelece concomitantemente entre as funções do Ministério Público a promoção exclusiva da ação penal pública e a defesa do regime democrático: “Art. 127: O Ministério Público é instituição permanente, essencial à função jurisdicional do Estado, incumbindo-lhe a defesa da ordem jurídica, do regime democrático e dos interesses sociais e individuais indisponíveis. Art. 129. São funções institucionais do Ministério Público: I - promover, privativamente, a ação penal pública, na forma da lei”.
} 
investigação criminal. Este tema é hoje foco de polêmica, no que tange à possibilidade de o Ministério Público conduzir investigação.

A origem de tal discussão pode servir de indicativo inicial a respeito dos aspectos em torno dos quais ronda o tema. Isto porque o Ministério Público brasileiro, conquanto historicamente se tenha valido de inquéritos policiais como instrumentos de coleta de provas para a propositura de ações penais, não raras vezes se valeu e se vale, de elementos de prova oriundos de outros feitos, como sempre foi o caso, por exemplo, dos procedimentos falimentares, ou mesmo as investigações de delitos que envolvem os agentes do Ministério Público, que são realizadas exclusivamente pelo Procurador Geral de Justiça, a teor do art. 41, parágrafo único, da Lei $n^{0}$ 8.625/93. Aliás, foi justamente a existência da possibilidade de investigação pelo Ministério Público que gerou a necessidade da regulamentação desta atividade pelo Conselho Nacional do Ministério Público, através da edição da resolução $n^{\circ} 13$ de 2 de outubro de 2006. Não é de supor que o Conselho Nacional tenha regulamentado uma ilegalidade ou uma inconstitucionalidade.

Poder-se-ia aventar que esta faculdade do órgão acusador não teria sido combatida antes do advento da Carta Constitucional de 1988 porque ele então se encontrava sob o manto protetivo do Executivo, contra quem, em um Estado ditatorial, não se brande, usualmente, a pena crítica.

Por outro lado, também é possível enxergar, no advento da Constituição chamada de "Cidadã”, o desenho de um novo Ministério Público, defensor do regime democrático e com atribuições crescentes e variadas em aspectos relativos ao patrimônio público, ao meio ambiente, às garantias constitucionais das minorias, postura que certamente implicou em um incremento persecutório criminal do chamado "criminoso do colarinho branco”. É inegável a coincidência do aumento da intervenção do Ministério Público na investigação e persecução de agentes socialmente poderosos e a ampliação constitucional de suas atribuições (MACHADO, 2009, p. 36-37).

Esta realidade criminológica também certamente guarda relação com a abrupta reação a que o Ministério Público possa valer-se de outras fontes além do inquérito policial para auferir provas e indícios 
para a propositura da ação penal. Atrelar o Ministério Público à atividade da polícia judiciária implica submetê-lo, por via oblíqua e indireta, à influência e controle seletivo da imputação realizado pelo Poder Executivo. Obviamente, enquanto dos inquéritos policiais brota a incriminação dos excluídos sociais bem identificados pela Criminologia Crítica, ${ }^{24}$ dos inquéritos civis, autuações fiscais e ações de improbidade brotam os indícios de incriminação dos poderosos agentes infiltrados nas instâncias de poder e dos hipersuficientes econômicos. ${ }^{25}$

Outra evidência da existência de outros interesses além da preservação de garantias individuais na pretensão de vedação da possibilidade investigatória do Ministério Público é revelada pela própria fragilidade dos argumentos principais que amparam tal tese. Diz-se que os agentes do Ministério Público, ao realizarem investigações preparatórias, perderiam a sua imparcialidade para exercitar a ação penal em juízo, já que o Ministério Público, além de titular dessa ação também tem incumbência, simultânea, de velar pelo cumprimento da lei. Em segundo lugar, afirma-se que a função investigatória preliminar de delitos seria função exclusiva da polícia judiciária.

Ora, se estamos em pleno caminho da adoção de um modelo acusatório, nada mais lógico do que o Ministério Público assumir sua condição de parte. Sendo parte, não estaria jamais equidistante da prova. Não haveria contaminação possível. Aliás, a parcialidade do Ministério Público é condição básica do estabelecimento do contraditório no processo, diante da defesa. ${ }^{26}$

No sistema acusatório, a investigação criminal visa a formação de um caso a ser proposto pelo Ministério Público à apreciação do juiz. Toda a investigação, portanto, não tem um outro objetivo além de

24 Veja-se, a respeito, um bom resumo sobre os processos de criminalização e etiquetamento na obra: Introdução à Criminologia, de Muñoz Conde e Hassemer (2006, p. 91).

25 “As pessoas de classe socioeconômica alta participam em muitas condutas delitivas”, porém, é certo que "este comportamento criminoso difere do da classe socioeconômica baixa principalmente nos procedimentos administrativos utilizados no tratamento dos delinquentes" (SUTHERLAND, 2009, p. 9).

${ }^{26}$ Nesse sentido, a opinião de Antonio Alberto Machado (2009, p. 36-37) em Curso de Processo Penal. 
oferecer elementos que permitam ao órgão encarregado da acusação levar a cabo uma pretensão final de aplicação de pena. Conforme comenta Antônio Alberto Machado, “não seria lógico que o interessado direto nas investigações criminais, com poderes para exercitar a ação penal baseada em elementos proporcionados por essa investigação, não pudesse, ele próprio, nos termos da lei, levar a efeito as diligências investigatórias necessárias ao desempenho de suas funções” (MACHADO, 2009, p. 35-36).

Além disso, o inquérito policial, produto final da atividade policial, sempre foi considerado instrumento facultativo e plenamente dispensável para o exercício do direito de ação pelo Ministério Público (TOURINHA FILHO, 1982, p. 175-176; FREDERICO MARQUES, 1961, p. 76-79, 143, 146, 147; TORNAGHI, 1997, p. 138).

De mais a mais, a questão da imparcialidade das investigações está, no mínimo, mal focada (LOPES JUNIOR, 2007, p. 327). O problema efetivamente não é quem exercita o poder investigatório, mas sim que garantias possui o investigado. Conforme refere Aury Lopes Júnior, "muito mais importante do que decidir quem vai fazer a inquisição (MP ou Polícia), está em definir como será a inquisição, sempre mantendo o juiz - obviamente - bem de longe de qualquer iniciativa investigatória” (p. 329). Desde um ponto de vista teórico, é claro que o órgão que tem atribuição de defesa do regime democrático tende a oferecer mais garantias ao investigado do que outro que não cumula a mesma atribuição. ${ }^{27}$ Assim, não se poderia esperar outra coisa de um ponto de vista prático, que não ser notório que os principais atentados contra as garantias fundamentais de investigados acontecem precisamente nas investigações realizadas pela

27 Sustenta Eugenio Pacelli de Oliveira: “deve-se lembrar que a Constituição de 1988 é um instrumento normativo amplamente oxigenado pelos ares da democracia, e que teve a nítida e reconhecida finalidade de romper com os traços autoritários da ordem política e jurídica anterior. Nesse passo, como compatibilizar, em uma hermenêutica constitucional principiológica, que constrói um amplo sistema de liberdades públicas, fundado na proteção aos direitos fundamentais - eis o princípio do Estado Democrático de Direito -, a ideia de uma Constituição cidadã com a reserva das investigações para a polícia? Qual seria a razão de semelhante opção?” (OLIVEIRA, 2009, p. 74-75). 
polícia. ${ }^{28}$ Não é outra a razão pela qual na declaração da IX Conferência Nacional dos Direitos Humanos, ficou constando menção expressa no sentido do incentivo à afirmação dos poderes investigatórios do Ministério Público, como forma de melhor preservar os direitos humanos. ${ }^{29}$

Enfim, o ponto chave da questão investigatória é que tanto se realizada pelo Ministério Público, quanto se realizada pela polícia, deverá obedecer estritamente as garantias fundamentais do investigado e transcorrer dentro dos estreitos limites da constitucionalidade e da legalidade (MACHADO, 2009, p. 39).

De outro lado, a ideia de exclusividade da titularidade da investigação pela polícia judiciária não se sustenta nem mesmo em termos normativos.

O próprio Código de Processo Penal prevê de modo expresso, no parágrafo único do artigo $4^{\circ}$, o qual define a quem pertence o exercício da polícia judiciária que “a competência definida neste artigo não excluirá a de autoridades administrativas, a quem por lei seja cometida a mesma função”. Aí aparece, de modo expresso, a inexistência de um monopólio da investigação criminal, ou seja, a investigação pode ser exercida por outros órgãos além da polícia judiciária.

28 Quanto às benesses comparativas da adoção da figura do promotor investigador, convém referir o comentário de Aury Lopes Júnior: "Sempre dissemos que essa era a opção 'menos problemática', principalmente quando comparada com as demais (policial e judicial). Basta analisar as vantagens e inconvenientes de sua estrutura, bem como o funcionamento em sistemas concretos (Itália, Alemanha, Portugal e os híbridos Espanha e França), para concluir que a investigação a cargo do Ministério Público é aquela em que os inconvenientes (igualmente existentes) são mais facilmente contornáveis e passíveis de superação” (LOPES JÚNIOR, 2007, p. 329).

29 Trata-se do item 22 da Carta de Brasília, que menciona textualmente o seguinte: “A todo momento, vemos tentativa de limitação da ação do Ministério Público, na contramão da história. Queremos que o Ministério Público seja mais ativo, tenha garantida sua ação, inclusive com mais recursos financeiros e humanos para que possa realizar sua ação investigatória segundo os preceitos constitucionais, acompanhar processos, tomar iniciativa como guardião dos direitos dos cidadãos e das cidadãs. Queremos um Ministério Público ainda mais atuante, capaz de exercer o controle externo da atividade policial e, ao mesmo tempo, respeitar os direitos humanos, a dignidade e a imagem pública dos acusados”. A notícia aparece referida em Oliveira (2009, p. 76). 
A Constituição da República estabelece disciplina idêntica, posto que, no dispositivo de indicação da atividade investigatória - a saber, o art. 144, § $4^{\circ}$ - não menciona a exclusividade. E quando o faz - no art. 144 , § $1^{\circ}$, IV - apenas objetiva separar as atribuições da polícia federal em face das demais polícias judiciárias dos Estados-membros, ${ }^{30}$ reservando, em contrapartida, “a legitimação do Ministério Público para a apuração de infrações penais nos termos do disposto no art. 129, VI e VIII. ${ }^{31}$ A matéria é regulamentada no âmbito do Ministério Público Federal pela Lei Complementar $n^{0} 75 / 93$, arts. $7^{\circ}, 8^{\circ}$ e 38 , e no âmbito estadual pela Lei $n^{\circ}$ 8.625/93.

A tendência de coordenação das investigações criminais pelo Ministério Público, por um lado, em nada diminui o papel da polícia judiciária, porquanto há uma evidente diferenciação entre a realização dos atos investigatórios, propriamente ditos, coisa que é realizada pela polícia no inquérito policial e a investigação, ${ }^{32}$ enquanto descoberta de provas capazes de formar um caso, cuja coordenação lógica somente

30 “A Constituição da República, a todas as luzes, não a contempla no Capítulo que cuida da Segurança Pública (art. 144 e seguintes, CF). A única menção feita à exclusividade que ali se contém diz respeito ao disposto no art. 144, § $1^{\circ}$, IV, no qual se estabelece caber à Polícia Federal, com exclusividade, as funções de Polícia Judiciária. Ora, mesmo no campo da hermenêutica puramente gramatical, veríamos que a exclusividade ali contida diria respeito unicamente À Polícia Federal, em relação, portanto, às investigações da Justiça Federal. Relembre-se: há também a Polícia Rodoviária Federal! Daí, a distinção. Então, o máximo que se poderia alegar é que somente a Polícia Federal - e não a estadual - teria privatividade na investigação, já que em relação à Polícia Estadual (polícias civis) nada se afirma no âmbito de qualquer exclusividade (art. 144, § 4, $\mathrm{CF}$ ). Por isso, a contrario sensu - é no campo da hermenêutica clássica que estamos operando -, não haveria impedimento às investigações ao Ministério Público dos estados” (OLIVEIRA, 2009, p. 74. No mesmo sentido, Machado (2009, p. 37).

31 Nesse sentido, Oliveira (2009, p. 71-72) comenta que a natureza constitucional de tais atribuições foi reconhecida de modo unânime pelo Supremo Tribunal Federal no julgamento do $\mathrm{HC} \mathrm{n}^{\circ}$ 77.770/SC, sendo relator o Ministro Néri da Silveira. Também Demercian e Maluly (2009, p. 74).

32 O termo investigação tem a conotação de pesquisa, no sentido de coleta de dados, coisa que certamente é de atribuição daquele que organiza os dados e apresenta os resultados; o que difere completamente de inquérito, que traduz a realização de inquirições, o ato prático de obtenção de elementos que poderão ou não servir de dados para a investigação. 
pode estar dirigida por aquele a quem incumbirá levar o caso a juízo. ${ }^{33}$ Esta é uma tendência mundial, conforme revela o Codice di Procedura Penale italiano, que determina expressamente em seu art. 51, que uma das funções exercidas pelo Ministério Público é a atuação na investigação preliminar, ${ }^{34}$ situação que é admitida sem maiores questionamentos em vários outros sistemas, como o alemão, o chileno e o francês, por exemplo (OLIVEIRA, 2009, p. 76).

O projeto de novo Código de Processo Penal revela a postura de que o Ministério Público é, ao mesmo tempo, responsável e destinatário final da investigação, na mesma medida em que o Judiciário é destinatário final da produção probatória para fins de prestação jurisdicional.

Um dos elementos mais reveladores deste aspecto é a tratativa dada ao tema do arquivamento do inquérito policial. Ao contrário da atual diretriz do artigo 28 que submete o arquivamento do inquérito policial à apreciação do judiciário, ainda que com o resguardo da última palavra a respeito da disposição da ação penal para o procurador-geral de Justiça, o novo projeto contempla, no artigo 38, tão somente a possibilidade de o Ministério Público comunicar a vítima, o investigado, a autoridade policial e sua própria instância de revisão a respeito da providência do arquivamento. Conforme referido na própria exposição de motivos do projeto, ${ }^{35}$ a providência visa a claramente produzir dois efeitos. Por um lado, evitar o exercício de uma superioridade hierárquica do agente ministerial sobre o agente judiciário, eis que a última palavra a respeito do

\footnotetext{
33 “É inegável que a apuração das infrações penais cabe, primordialmente, à autoridade policial; porém, se esta não proceder a uma adequada investigação de fato, em prejuízo da persecução penal, a interferência do Ministério Público verificar-se-á para assegurar o sucesso dessa atividade, na qual o dominus litis tem evidente interesse. Na realidade, quando o Ministério Público promove sua pesquisa direta, não está presidindo um "inquérito policial”: move-se nos limites de investigação própria, peculiar e inconfundível com a desenvolvida pela Polícia Civil” (DEMERCIAN; MALULY, 2009, p. 82).

34 Art. 51 - Uffici del pubblico ministero. Attribuzioni del procuratore della Repubblica distrettuale.

1. Le funzioni di pubblico ministero sono esercitate (disp. di att.c.p.p.3):

a) nelle indagini preliminari e nei procedimenti di primo grado dai magistrati della procura della Repubblica presso il tribunale.

35 Item III da Exposição de motivos do projeto de Código de Processo Penal.
} 
arquivamento ficava nas mãos do procurador-geral de Justiça. Por outro lado, respeita-se o interesse da vítima no que tange ao controle pela via do questionamento da correção da providência de arquivamento. Revela-se aqui a condição de sujeito processual do Ministério Público, uma vez que, no sistema acusatório público, detém a titularidade da ação penal, pois a ele incumbe representar interesse público. Uma indevida interferência do judiciário neste momento significaria conferir ao órgão encarregado da prestação jurisdicional parte do interesse persecutório; confundiu-se outra vez sua condição de sujeito no processo com aquela que pertence ao Ministério Público.

Ainda sobre esse tema, a distribuição de títulos e capítulos do projeto deixa clara uma distinção que por vezes tem levado a confusões de interpretação a respeito do alcance da capacidade investigatória do Ministério Público. O projeto fixa no título II a investigação criminal como gênero, para distribuir nos capítulos, mais precisamente no capítulo III, o inquérito policial como espécie. Não há qualquer dúvida de que o inquérito policial é o instrumento básico mais importante na composição da investigação que vai subsidiar o Ministério Público na composição da sua pretensão acusatória. Isto não quer dizer, porém, que haja, ao contrário, uma dependência de parte do Ministério Público em face do inquérito policial como seu instrumental prévio de reunião de dados que vão compor o caso para ser submetido ao juízo de admissibilidade de parte do judiciário. Sendo assim, resta inequivocamente invalidada a pretensão da criação de uma relação de dependência da investigação do Ministério Público, parte única e legítima para a formulação do caso, em face do inquérito policial como peça formal. Convém lembrar que o artigo $8^{\circ}$ do projeto estabelece os objetivos claros da investigação criminal como sendo a reunião das fontes de prova, e para demonstração de fundamento razoável a respeito da prática da infração penal. Obviamente, essas provas não derivarão unicamente da atividade policial, podendo o Ministério Público valer-se das fontes que considere adequadas e razoáveis à demonstração do caso.

Nem se diga que a possibilidade de obtenção de provas por outra via que não o inquérito policial desnatura de algum modo as garantias do investigado, uma vez que os artigos 11, 12, 13 e 14 do projeto estabelecem 
claramente uma vasta rede de garantias ao investigado eu seu defensor para que possam produzir, ainda neste âmbito, elementos capazes de convencer a respeito da inexistência no caso.

Convém ainda referir que, dos mesmos dispositivos que contemplam especificadas as garantias do acusado diante da investigação, a referência ao autor da investigação é sempre como autoridade, e não como autoridade policial, o que certamente evidencia a pretensão do projeto em estabelecer um âmbito mais amplo para a investigação do que aquele reduzido ao inquérito policial, sem com isso permitir que o órgão destinatário da investigação - o Ministério Público - por sua iniciativa, possa de algum modo comprometer as garantias fundamentais do acusado.

Se o sujeito processual encarregado da acusação é o Ministério Público e esta é a sua posição como sujeito do processo, é óbvio que a ele incumbe o comando da investigação criminal, exercendo não só o poder de seleção e organização das provas a serem apresentadas como caso ao judiciário, como ainda exercendo sua tarefa constitucional primordial de controle externo da atividade policial, também no campo da investigação.

Esse aspecto do projeto também revela a posição do Ministério Público como sujeito do processo penal.

\section{Conclusões}

É evidente, portanto, que, com o novo projeto de Código de Processo Penal, estamos diante de um passo mais no sentido da evolução do modelo persecutório e da adequada situação processual dos sujeitos, especialmente do Ministério Público. Descortina-se aí a possibilidade concreta de que o Ministério Público assuma o seu lugar de direito no âmbito do processo penal, sem que isso implique na perda do perfil constitucionalmente adotado a partir de 1988.

Ou seja, a assunção da condição de parte, com o comando a investigação, a formulação do caso e sua concreção perante o judiciário através da efetiva produção da prova trazem para os agentes de execução 
do Ministério Público uma real condição de dominus litis da ação penal a qual vem recheada de responsabilidades.

A primeira delas - em escala cronológica, já que em importância são iguais - é focada no efetivo exercício do comando da investigação, que implica não apenas em um dever de controle externo do abuso policial, mas muito mais no sentido do estabelecimento de prioridades e de direcionamento das investigações, já sejam elas realizadas no corpo de um inquérito policial, de um inquérito civil ou de qualquer outra classe de coleta de dados probatórios. Aqui, a tarefa vai cumulada com o controle do efetivo respeito aos direitos e garantias fundamentais dos investigados, enquanto expressão concreta da tarefa constitucionalmente impingida de proteção do regime democrático.

Em seguida, e não por isso menos importante, surge a responsabilidade de situar-se dentro do processo penal como parte legítima da produção probatória, no sentido de efetivar a realização da prova no processo, preservando o juiz de eventuais e indesejáveis contaminações com o exercício de provar. Para tanto, é fundamental que os agentes de execução do Ministério Público efetivamente conheçam os processos em curso antes da realização das audiências de instrução ou das provas periciais, e atuem de modo efetivo em busca da confirmação ou do desmentido do caso.

Tais mudanças que efetivamente estão a caminho e a sua exata compreensão pelos sujeitos por elas afetados são elementos fundamentais na evolução do processo penal brasileiro como instrumento de garantias contra a intervenção do Estado na vida do indivíduo. Um processo que finalmente seja um processo de partes é a única fórmula que propõe um ideal de justiça em substituição a uma pretensão de verdade que a tudo justifica. Seu efetivo estabelecimento só será possível a partir de que as partes tenham plena consciência do que efetivamente são, e que os juízes assumam sua condição de sujeitos equidistantes do processo.

Afinal, todos sabem a que tipo de interesses serviu a substituição de uma pretensão processual de justiça - mesmo que imprecisa, eis que oriunda da atividade humana -, por um processo que premiava uma verdade injusta. 


\section{Referências}

BACILA, C. R. Estigmas: um estudo sobre os preconceitos. Rio de Janeiro: Lumen Juris, 2005.

DEMERCIAN, P. H.; MALULY, J. A. Curso de processo penal. 4. Ed. Rio de Janeiro: Forense, 2009.

FEITOZA, D. Reforma processual penal. Niterói: Impetus, 2008.

FREDERICO MARQUES, J. Elementos de direito processual penal. v. 1. Rio de Janeiro: Forense, 1961.

HABERMAS, J. Direito e democracia: entre faticilidade e validade I. trad. de Flávio Beno Siebeneichler. Rio de Janeiro: Tempo Brasileiro, 2003.

LOPES JÚNIOR, A. Direito processual penal e sua conformidade constitucional. v. 1. Rio de Janeiro: Lumen Juris, 2007.

MACHADO, A. A. Curso de processo penal. 2. ed. São Paulo: Atlas, 2009.

MUÑOZ CONDE, F. La búsqueda de la verdad real en el proceso penal. 2. ed. Buenos Aires: Hammurabi, 2003.

MUÑOZ CONDE, F.; GARCÍA ARÁN, M. Derecho penal: parte general. 7. ed. Valencia: Tirant lo Blanch, 2007.

MUÑOZ CONDE, F.; HASSEMER, W. Introdução à criminologia. Trad. de Cíntia Toledo Miranda Chaves. Rio de Janeiro: Lumen Juris, 2006.

OLIVEIRA, E. P. Curso de processo penal. 11. ed. Rio de Janeiro: Lumen Juris, 2009.

RANGEL, P. Direito Processual Penal. 16. ed. Rio de Janeiro: Lumen Juris, 2009.

SANTOS, J. C. Direito penal: parte geral. 3. ed., Curitiba/Rio de Janeiro: ICPC/Lumen Juris, 2008.

SUTHERLAND, E. El delito de cuello blanco. Trad. de Laura Belloqui. Montevideo/Buenos Aires: BdeF, 2009. 
TORNAGHI, H. Curso de processo penal. 10. ed. São Paulo: Saraiva, 1997.

TOURINHO FILHO, F. C. Prática de processo penal. São Paulo: Jalovi, 1982.

VIVES ANTÓN, T. S. Fundamentos del sistema penal. Valencia: Tirant lo Blanch, 1996.

VOLK, C. La verdad sobre la verdad y otros estudios. Trad. de Eugenio Sarrabayrouse. Buenos Aires: Ad-hoc, 2007.

Recebido em: 03/04/2010 Revisado em: 25/04/2010 Aprovado em: 03/05/2010 